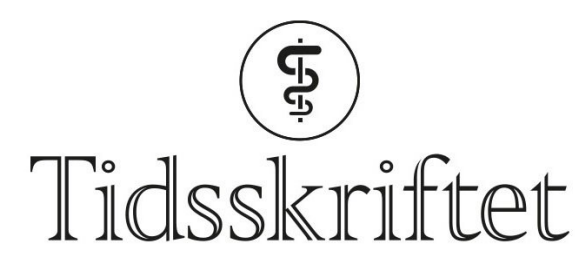

DEN NORSKE LEGEFORENING

\title{
G.L. Sporaland og medarbeidere
}

\section{svarer}

KOMMENTAR

\section{GEIR LINDQUIST SPORALAND}

E-post: glsporaland@gmail.com

Geir Lindquist Sporaland er fastlege.

\section{GUNNAR MOULAND}

BJØRN BRATLAND

\section{ELLEN RYGH}

\section{HARALD REISO}

Ingen av forfatterne har oppgitt noen interessekonflikter.

Takk til Gry Grøneng og Trine Hessevik Paulsen fra Folkehelseinstituttet for interesse for artikkelen og verdifull innsikt i hvordan FHI benytter seg av KUHR-data. Vi vil samtidig minne om at det særlig er for konsultasjoner at vi finner godt samsvar mellom diagnosekoder og journalnotat.

Publisert: 3. februar 2020. Tidsskr Nor Legeforen. DOI:10.4045/tidsskr.20.0028

(C) Tidsskrift for Den norske legeforening 2020. Lastet ned fra tidsskriftet.no 